\title{
PENERAPAN METODE PEMBELAJARAN KOOPERATIF MAKE MATCH DENGAN MEDIA KARTU BRAILLE UNTUK MENINGKATKAN AKTIVITAS DAN HASIL BELAJAR BAHASA INDONESIA
}

\author{
Lasmaria Lestrina \\ Guru SLB-A Yapentra Tanjung Morawa, Sumatera Utara \\ lasmaria_lestrina@gmail.com
}

\begin{abstract}
Abstrak: Tujuan penelitian tindakan yang hendak dicapai adalah: (1) Untuk mengetahui peningkatkan aktivitasi belajar siswa tunanetra melalui tindakan penerapan pembelajaran kooperatif Make A Match dengan media kartu Braille. (2) Untuk mengetahui peningkatkan hasil belajar Bahasa Indonesia siswa tunanetra melalui tindakan penerapan Pembelajaran Kooperatif Make A Match dengan media kartu Braille. Penelitian ini dilaksanakan di SLB-A Yapentra (Yayasan Pendidikan Tunanetra Sumatera) Km. 21,5 Tanjung Morawa.Subjek penelitian adalah siswa SLB-A Yapentra Tanjung Morawa, yaitu kelas VI, yang berjumlah 6 (enam) orang. Hasil penelitian tindakan menunjukkan bahwa: (1) dengan menerapkan metode pembelajaran kooperatif Make A Match dengan media kartu braille, aktivitas siswa dalam setiap siklus terus meningkat terutama ketika siswa dibagi kedalam kelompok dalam mencocokan pasangan kartu braille. (2) dengan menerapkan metode pembelajaran kooperatif Make A Matc dengan media kartu braille dapat meningkatkan hasil belajar Bahasa Indonesia khususnya dalam pembelajaran "Membaca Intensif"
\end{abstract}

Kata Kunci: metode pembelajaran kooperatif, make match, media kartu braile, aktivitas, bahasa indonesia

Abstract: The objectives of the action research to be achieved are: (1) To know the improvement of learning activation of blind students through the action of implementing cooperative learning Make A Match with Braille media card. (2) To know the improvement of learning result of Indonesian blind students through the action of implementing Cooperative Learning Make A Match with Braille media card. This research was conducted at SLB-A Yapentra (Yayasan Pendidikan Tunanetra Sumatera) Km. 21,5 Tanjung Morawa. The subject of the research is the students of SLB-A Yapentra Tanjung Morawa, namely class VI, which is 6 (six) people. The results of action research show that: (1) by applying cooperative learning method of Make A Match with braille media card, student activity in each cycle keep increasing especially when students are divided into groups in matching braille card pairs. (2) by applying cooperative learning method of Make A Matc with media of braille card can improve learning result of Indonesian especially in learning "Reading Intensive"

Keywords: cooperative learning method, make match, media card braile, activity, indonesian language

\section{PENDAHULUAN}

Anak tunanetra sebagai mana anak lainnya, membutuhkan pendidikan untuk mengembangkan potensi yang dimilikinya secara obtimal. Oleh karena adanya gangguan penglihatan, anak tunanetra membutuhkan layanan khusus untuk merehabilitasi kelainannya yang meliputi latihan membaca dan menulis braille, penggunaan tongkat, Orientasi \& Mobilitas, serta latihan fisual/ fungsional penglihatan. Layanan pendidikan bagi anak tunanetra dapat dilaksanakan melalui segregasi yaitu secara terpisah dari anak awas (dapat melihat) dan integrasi atau terpadu dengan anak awas disekolah biasa. Bentuk layanan segregasi bagi ABK (Anak Berkebutuhan Khusus) adalah terselenggaranya program pendidikan Luar Biasa (SLB, SDLB) bagi anak yang menyandang ketunaan. Salah satu diantaranya SLB-A yakni Sekolah Luar 
Biasa khusus mendidik anak penyandang tunanetra.

Beberapa lembaga pendidikan dalam mengkaji ketunanetraan masih terlihat membahas 'penderita tunanetra' yang menekankan pada berbagai faktor penyebab kecacatan dan dampaknya, masalah yang dihadapi, serta kemampuan yang dimilikinya, sehingga kecenderungan layanan pendidikan adalah Pendidikan bagi Anak Tunanetra berupa hal-hal apa saja yang bisa dilakukan oleh tunanetra dengan terbatas pada ketunanetraannya.

Dampak dari pemahaman di atas dapat mengakibatkan proses pembelajaran yang kaku dan monoton sehingga aktivitas pembelajaran siswa tunanetra di dalam kelas sangat minim. Mereka hanya duduk manis sebagai pendengar yang baik, menulis, membaca dan sesekali bertanya. Guru terpaku pada hal-hal apa saja yang bisa dilakukan oleh tunanetra dengan terbatas pada ketunanetraannya. Hal ini jugalah yang terjadi di SLB-A Yapentra. Dalam pengamatan penulis ketika berlangsung pembelajaran Bahasa Indonesia, aktivitas belajar yang terjadi hanya berfokus pada guru. Siswa lebih sering sebagai pendengar, menulis, membaca jika disuruh, sesekali menjawab pertanyaan jika diminta. Karena kondisi visual siswa yang terbatas, secara umum guru SLB-A sering ragu melakukan metode mengajar yang membutuhkan mobilitas siswa.

Bila dilihat dari proses pembelajaran Bahasa Indonesia yang dilaksanakan di SLB-A selama ini, kompetensi-kompetensi yang harus dikuasai siswa disajikan dengan metode ceramah dan tanya jawab yang lebih mengandalkan kemampuan mengajar guru dengan lebih sedikit memberikan kesempatan bagi anak didik untuk berinteraksi aktif sebagai cermin pengetahuan dan kemampuan anak didik dalam memperoleh ilmu pengetahuan di kelas. Guru lebih banyak berceramah, menjelaskan materi dengan segenap kemampuannya namun tidak menimbulkan aktivitas belajar yang baik, kurang menggunakan media pembelajaran sehingga siswa menjadi bosan. Kebosanan siswa tampak dalam bentuk mengantuk, melakukan adatan atau Blindisim (gerak-gerik atau tingkah laku serta kegiatan atau timbulnya suara yang tidak jelas arti ataupun tujuannya), dan lain-lain.

Menurut Slameto (2010:36) "dalam proses belajar mengajar, guru perlu menimbulkan aktivitas siswa dalam berpikir maupun berbuat. Penerimaan pelajaran jika dengan aktivitas siswa itu sendiri, kesan itu tidak akan berlalu begitu saja, tetapi dipikirkan, diolah, kemudian dikeluarkan lagi dalam bentuk yang berbeda atau siswa akan bertanya, mengajukan pendapat, menimbulkan diskusi dengan guru. Bila siswa menjadi partisipasi aktif, maka ia memiliki ilmu/ pengetahuan yang baik".

Hamalik (2010:175) menyatakan bahwa "penggunaan aktivitas besar nilainya bagi pengajaran para siswa, oleh karena : (1) Para siswa mencari pengalaman sendiri dan langsung mengalami sendiri. (2) Berbuat sendiri akan mengembangkan seluruh aspek pribadi siswa. (3) Memupuk kerjasama yang harmonis dikalangan siswa. (4) Para siswa bekerja menurut minat dan kemampuan sendiri. (5) Memupuk disiplin kelas secara wajar dan suasana belajar menjadi demokratis. (6) Mempererat hubungan sekolah dan masyarakat, dan hubungan antara orang tua dengan guru. (7) Pengajaran diselenggarakan secara realistis dan konkrit sehingga mengembangkan pemahaman dan berpikir kritis serta menghindarkan verbalistis. (8) Pengajaran di sekolah menjadi hidup sebagaimana aktivitas dalam kehidupan di masyarakat".

$$
\text { Menurut Kagan (1992) bahwa }
$$
cooperative learning adalah metode pembelajaran yang memberi kesempatan kepada siswa untuk aktif mengambil bagian dan bekerja secara kooperatif sehingga mereka sanggup berkomunikasi, berinteraksi dengan yang lain. Menurut Lie (2000:38) dikatakan bahwa cooperative learning merupakan proses belajar mengajar yang melibatkan niat dan kiat para anggota kelompok dalam mencapai tujuan pembelajaran yang telah ditetapkan.

Secara sederhana kata kooperatif berarti mengerjakan sesuatu secara bersama-sama dengan saling membantu satu sama lainnya sebagai suatu tim. Jadi pembelajaran kooperatif dapat diartikan belajar bersama-sama, saling membantu antara satu dengan lain dalam belajar dan memastikan bahwa setiap orang dalam kelompok mencapai tujuan atau tugas yang telah ditentukan sebelumnya. (Isjoni, 2009)

Pembelajaran Make A Match (mencari pasangan) adalah suatu metode pembelajaran dalam pendekatan cooperative learning yang dikembangkan oleh Lorna Curan (1994). Salah satu keunggulan teknik ini adalah "siswa mencari pasangan sambil belajar mengenai konsep atau topik dalam suasana yang 
menyenangkan" (Isjononi,2009:112). Teknik Make A Matc ini dapat digunakan dalam semua mata pelajaran dan untuk semua tingkatan usia anak didik. (Lie, 2010:55)

Berkenaan dengan perkembangan gerak anak tunanetra, Renell (1978) menyatakan bahwa anak tunanetra (khususnya ketunanetraan bawaan) memperlihatkan keterlambatan perkembangan motoriknya. Keterlambatan ini dimulai pada usia 6 (enam) sampai 8 (delapan) bulan dan berlangsung hingga masa prasekolah. Pada usia 5 (lima) tahun, perkembangan motorik rata-rata anak tunanetra berada 12 bulan tertinggal dari anak awas. Untuk mengembangkan rasa percaya diri dan kemandirian dalam bepergian, anak tunanetra membutuhkan intervensi yang tepat sejak usia dini dalam mengembangkan keterampilan motorik dan gerakannya secara terorganisasi dan bertujuan.

Media Pembelajaran yang umum digunakan siswa tunanetra di beberapa Sekolah Luar Biasa (SLB) meliputi: alat bantu menulis huruf Braille (Reglette, Pen dan mesin ketik Braille); alat bantu membaca huruf Braille (Papan huruf dan Optacon); alat bantu berhitung (Cubaritma, Sempoa, Speech Calculator), serta alat bantu yang bersifat audio seperti tape-recorder. Khusus Alat bantu membaca huruf Braille adalah alat bantu pembelajaran untuk mengenal huruf Braille, alat ini biasa disebut pantule singkatan dari Papan Tulis Braille. Alat ini terdiri dari pakupaku yang dapat ditempel pada papan sehingga membentuk kombinasi huruf Braille.

Dalam penelitian ini media yang akan digunakan adalah Media Kartu Braille. Kartu Braille adalah kartu yang berisi kata atau kalimat dengan tulisan Braille sesuai kebutuhan atau pencapaian tujuan pembelajaran Bahasa Indonesia yang diajarkan. Misalnya melengkapi kalimat, pada kartu yang panjang tertulis kalimat dengan satu kata hilang. Pada kartu tersebut diberi celah atau titik-titik (....) untuk kata yang hilang. Kemudian membuat kartu jawaban yang cocok dengan celah itu. Dalam melatih kosa kata siswa dapat juga digunakan media kartu. Guru menempelkan beberapa kartu di papan yang berisi tentang beberapa istilah umum seperti manusia, alam, binatang. Siswa Siswa pun sudah mendapatkan kartu berisi kosa kata yang berhubungan dengan suara yang diperdengarkan oleh manusia, binatang, dan alam. Misalnya: mengerang, berhembus, mengembik, dan lain sebagainya. Agar tidak ribut, siswa diminta memasang kartu-kartu mereka di papan tanpa bicara.

Index Card Match adalah permainan untuk melatih pengetahuan tentang lawan kata (antonim). Misalnya: gelap - terang, tinggi rendah, dan lain-lain. Cara bermain, siswa harus mencari rekannya yang memiliki kartu dengan kata yang berlawanan dengan kata pada kartu miliknya. Selanjutnya mereka harus duduk atau berdiri berdekatan. Permainan ini juga bisa dilakukan tanpa mengeluarkan suara sehingga ekspresi yang muncul akan lebih menarik, suasana kelas pun tidak terlalu ribut (karena walaupun tanpa suara, bunyi-bunyi yang dikeluarkan pun tetap saja lucu).

Menyusun Cerita Adalah alternatif permainan yang dilakukan untuk melatih kemampuan siswa menyusun satu paragraf yang logis. Caranya sebagai berikut: Kartukartu ditempelkan di dinding, dan para siswa diminta menyusun kartu-kartu tersebut menjadi satu jalinan cerita yang utuh dan bermakna.

Kesesuaian media pembelajaran dan materi pelajaran diharapkan akan meningkatkan aktivitas dan hasil belajar siswa. Kesesuaian tersebut juga harus memperhatikan situasi dan kondisi siswa sebagai warga belajar. Baik bentuk, cara menggunakan serta keamanan dan kenyamanan seorang tunanetra harus juga menjadi pertimbangan dalam pemilihan media.

Setiap orang tunanetra memiliki keterampilan orientasi dan mobilitas yang sangat beragam. Secara logika tampaknya orang yang masih memiliki sisa penglihatan memiliki keterampilan orientasi dan mobilitas lebih baik dibandingkan dengan orang yang buta total. Hal ini diduga bahwa dengan penglihatan seseorang dapat melakukan pergerakan dengan baik dan terkontrol. Akan tetapi, selain faktor gradasi dan waktu terjadinya kecacatan, dukungan dan kesempatan yang diberikan oleh lingkungan serta faktor motivasi dari dalam diri individu tunanetra itu sendiri dapat mempengaruhi keterampilan orientasi dan mobilitas tersebut.

Permasalahan penelitian sebagai berikut: (1) Bagaimana aktivitas belajar siswa tunanetra dalam pembelajaran Bahasa Indonesia melalui penerapan metode Pembelajaran Kooperatif Make A Match dengan menggunakan media kartu Braille? (2) Bagaimana hasil belajar Bahasa Indonesia siswa tunanetra melalui penerapan pembelajaran kooperatif Make A Match dengan menggunakan media kartu Braille? 


\section{METODE}

Penelitian ini dilaksanakan di SLB-A Yapentra ( Yayasan Pendidikan Tunanetra Sumatera) Km. 21,5 Tanjung Morawa, Kabupaten Deli Serdang, Provinsi Sumatera Utara. Perlakuan (tindakan) dilaksanakan selama 8 (delapan) kali pertemuan, terdiri atas dua siklus. Tiap siklus dilaksanakan 4 (empat) kali pertemuan dengan alokasi waktu $2 \times 40$ menit. Proses pembelajaran dilaksanakan di kelas dan disesuaikan dengan kalender akademik dan jadwal pelajaran yang ada.

Subjek penelitian adalah siswa SLB-A Yapentra Tanjung Morawa, yaitu kelas VI, yang berjumlah 6 (enam) orang. Keenam siswa tunanetra tersebut memiliki karakteristik sebagai berikut:

Tabel 1. Subjek Penelitian (Siswa)

\begin{tabular}{|c|c|c|c|c|c|c|c|}
\hline No & Nama & L/P & Umur & $\begin{array}{c}\text { Tingkat } \\
\text { Ketunanetraan }\end{array}$ & $\begin{array}{c}\text { Usia Terjadinya } \\
\text { Ketunanetraan }\end{array}$ & $\begin{array}{c}\text { Hambatan } \\
\text { Lain }\end{array}$ & $\begin{array}{c}\text { Tempat } \\
\text { Tinggal }\end{array}$ \\
\hline 1 & CL & L & 14 & Low Vision & & & Asrama \\
\hline 2 & DN & L & 14 & Buta Total & Sejak Lahir & - & Asrama \\
\hline 3 & EH & P & 14 & Buta Total & Sejak Lahir & - & Asrama \\
\hline 4 & LP & L & 13 & Low Vision & & $\begin{array}{c}\text { Konsentras } \\
\text { i (ringan) }\end{array}$ & Asrama \\
\hline 5 & LS & P & 14 & Buta Total & Sejak Lahir & - & Asrama \\
\hline 6 & YS & P & 13 & Buta Total & Sejak Lahir & - & Asrama \\
\hline
\end{tabular}

Penelitian ini dilakukan atas dasar temuan dan pengalaman peneliti sewaktu melaksanakan pembelajaran di SLB-A Yapentra Tanjung Morawa, secara khusus pada anak-anak tunanetra. Dari hasil temuan di dalam pendampingan dan pembelajaran anakanak tunanetra di lingkungan sekolah dan di kelas bahwa aktivitas dan hasil belajar Bahasa Indonesia mereka sangat kurang. Adanya masalah dan hambatan yang mereka alami, mengakibatkan mereka kurang aktif berinteraksi dalam proses pembelajaran. Hal ini sangat memepengaruhi pencapaian kompetensikompetensi Bahasa Indonesia selanjutnya. Dalam upaya memecahkan masalah dan mengkaji setiap permasalahan yang muncul dilakukan suatu kolaborasi, sehingga metode penelitian yang dipilih dalam penelitian ini adalah penelitian tindakan kelas. Metode penelitian ini dipilih dengan pertimbangan yang dianggap cukup obyektif dalam mengidentifikasi permasalahan anak-anak tunanetra tentang masalah hasil belajar tetapi kurang pengalaman dalam mencari solusi pemecahannya sehingga dibutuhkan pihak luar untuk melakukan suatu kolaborasi. Di samping itu penelitian tindakan juga memberikan kesempatan kepada peneliti untuk bertindak kreatif dalam praktek pembelajarannya sehingga dapat melakukan pembaharuan di dalam memecahkan masalah yang ditemui di kelas.
Melalui pertimbangan tersebut penelitian ini berusaha mengkaji serta merefleksikan secara kritis dan kolaboratif implementasi dari rencana pembelajaran yang telah disusun. Kajian difokuskan terhadap kinerja guru dalam menerapkan metode dengan menggunakan metode Cooperatif Learning Make A Match pada siswa-siswa tunanetra dalam suatu kealamiahan situasi kelas (natural setting) dengan tujuan untuk mengembangkan profesionlisme guru dalam meningkatkan hasil belajar Bahasa Indonesia anak-anak tunanetra di SLB-A Yapentra serta mampu menangani permasalahan pada siswa-siswi yang menyandang tunanetra.

Metode yang dilakukan dalam penelitian ini adalah Penelitian Tindakan Kelas (PTK) atau biasa disebut dengan Classroom Action Research (CAR). Penelitian tindakan kelas merupakan bentuk penelitian reflektif yang dilakukan oleh guru sendiri yang hasilnya dapat dimanfaatkan sebagai alat untuk pengembangan dan perbaikan pembelajaran. Para peneliti PTK tidak berasumsi bahwa hasil penelitiannya akan menghasilkan teori yang dapat digunakan secara umum (digeneralisasi). Penelitian tindakan hanya terbatas pada kepentingan peneliti sendiri, dengan tujuan agar penelitinya dapat melaksanakan tugas pembelajaran dengan lebih baik.

Untuk mengetahui keefektifan suatu metode dalam kegiatan pembelajaran perlu dilakukan analisis data. Proses analisa data 
dimulai dengan menelaah seluruh data yang tersedia. Data yang dikumpulkan atau yang diperoleh dari hasil pengamatan melalui teknik kolabarasi dengan lembar observasi angket, wawancara secara tertulis akan dianalisis. Pada penelitian tindakan kelas ini digunakan analisis kualitatif, yaitu suatu metode penelitian yang bersifat menggambarkan kenyataan atau fakta sesuai dengan data yang diperoleh dengan tujuan untuk mengetahui peningkatan aktivitas dan hasil belajar Bahasa Indonesia siswa.

Indikator keberhasilan penelitian ini adalah peningkatan aktivitas dan hasil belajar Bahasa Indonesia yang ditunjukkan dengan ciri-ciri para siswa menunjukkan interaksi yang aktif dalam kegiatan pembelajaran, sikap siswa yang antusias dan senang dalam belajar serta peningkatan hasil belajar Bahasa Indonesia khususnya membaca Intensif teks dan drama (Braille). Penelitian ini akan dihentikan apabila $90 \%$ siswa di kelas tersebut mendapat nilai $\geq 70$ dan telah menunjukkan keaktivan dan kemampuan membaca intensif yang baik.

\section{HASIL PENELITIAN}

Hasil observasi terhadap aktivitas siswa dalam kegiatan pembelajaran pada pertemuan pertama hingga pertemuan ketiga pada siklus pertama yang menggunakan metode pembelajaran kooperatif Make A Match dengan menggunakan kartu braille dapat dilihat pada tabel 4.2 analisis observasi di bawah ini dan format observasi aktivitas siswa.

Tabel 2 Analisis Observasi Aktivitas Siswa Siklus I

\begin{tabular}{|c|c|c|c|c|c|c|c|}
\hline \multirow{2}{*}{$\begin{array}{c}\mathrm{N} \\
\mathrm{O}\end{array}$} & \multirow[t]{2}{*}{ Kategori } & \multicolumn{2}{|c|}{$\begin{array}{c}\text { Pembelajaran } \\
\text { I }\end{array}$} & \multicolumn{2}{|c|}{$\begin{array}{c}\text { Pembelajaran } \\
\text { II }\end{array}$} & \multicolumn{2}{|c|}{$\begin{array}{c}\text { Pembelajaran } \\
\text { III }\end{array}$} \\
\hline & & $\begin{array}{c}\text { Frekue } \\
\text { nsi }\end{array}$ & $\begin{array}{c}\text { Persenta } \\
\text { se }(\%)\end{array}$ & Frekuensi & Persentase (\%) & Frekuensi & $\begin{array}{l}\text { Persenta } \\
\text { se }(\%)\end{array}$ \\
\hline 1 & $\begin{array}{l}\text { Sangat } \\
\text { Baik }\end{array}$ & 0 & 0,00 & 0 & 0,00 & 0 & 0 \\
\hline 2 & Baik & 3 & 50 & 5 & 83,33 & 6 & 100 \\
\hline 3 & Kurang & 3 & 50 & 1 & 16,66 & 0 & 0 \\
\hline 4 & $\begin{array}{l}\text { Sangat } \\
\text { Kurang }\end{array}$ & 0 & 0,00 & 0 & 0,00 & 0 & 0 \\
\hline
\end{tabular}

Dari tabel 2. terlihat bahwa pada pertemuan pertama dari enam orang siswa ada tiga orang yang aktif dalam proses pembelajaran, sedangkan tiga orang lainnya masih pasif. Pada pembelajaran ke dua terdapat lima orang yang aktif dan satu orang masih tetap pasif. Hasil observasi proses pada pertemuan pertama menunjukkan bahwa siswa belum terbiasa dengan penerapan metode pembelajaran Kooperatif Make A Match ini, mereka tampak malu-malu dan enggan. Pada pertemuan kedua terdapat sedikit peningkatan dimana terdapat satu orang pada pertemuan satu kurang aktif mulai menunjukkan perubahan positif. Sedangkan pada pertemuan ke tiga terdapat peningkatan dua orang yang pada pertemuan pertama kurang aktif sudah mengikuti pembelajaran dengan aktif dan satu orang siswa sangat aktif, mereka sudah mulai terbiasa dengan metode pembelajaran baru yang diterapkan, sehingga siswa yang kurang aktif berkurang dari empat menjadi dua orang.
Dari hasil analisis data observasi terhadap aktivitas siswa pada siklus pertama ini dapat disimpulkan bahwa kegiatan pembelajaran sudah cukup baik dan terdapat peningkatan aktivitas siswa dalam mengikuti pembelajaran, namun demikian keaktifan siswa masih sangat perlu ditingkatkan, karena masih terdapat dua orang siswa yang belum terbiasa dan tidak mampu mengimbangi temantemannya yang aktif. Keadaan ini dibuktikan dengan kondisi siswa yang masih terlihat bingung dengan metode pembelajaran yang baru mereka kenal dan mereka enggan, ragu melakukan apa yang seharusnya mereka kerjakan sehingga siswa menunjukkan perilaku yang tidak relevan seperti menunduk dan tidak mau berbicara terhadap teman sekelompoknya. Siswa terlihat canggung dengan adanya observer dan kamera sehingga siswa menjadi kikuk dan tidak konsentrasi dengan materi yang diajarkan guru. Keadaan yang paling mencolok adalah ada dua orang siswa yang masih punya sisa penglihatan (Lovision) tidak dapat 
menyimak dengan benar karena perhatiannya beralih mengamati gerak-gerik kedua observer

dan mempermainkan kameramen.

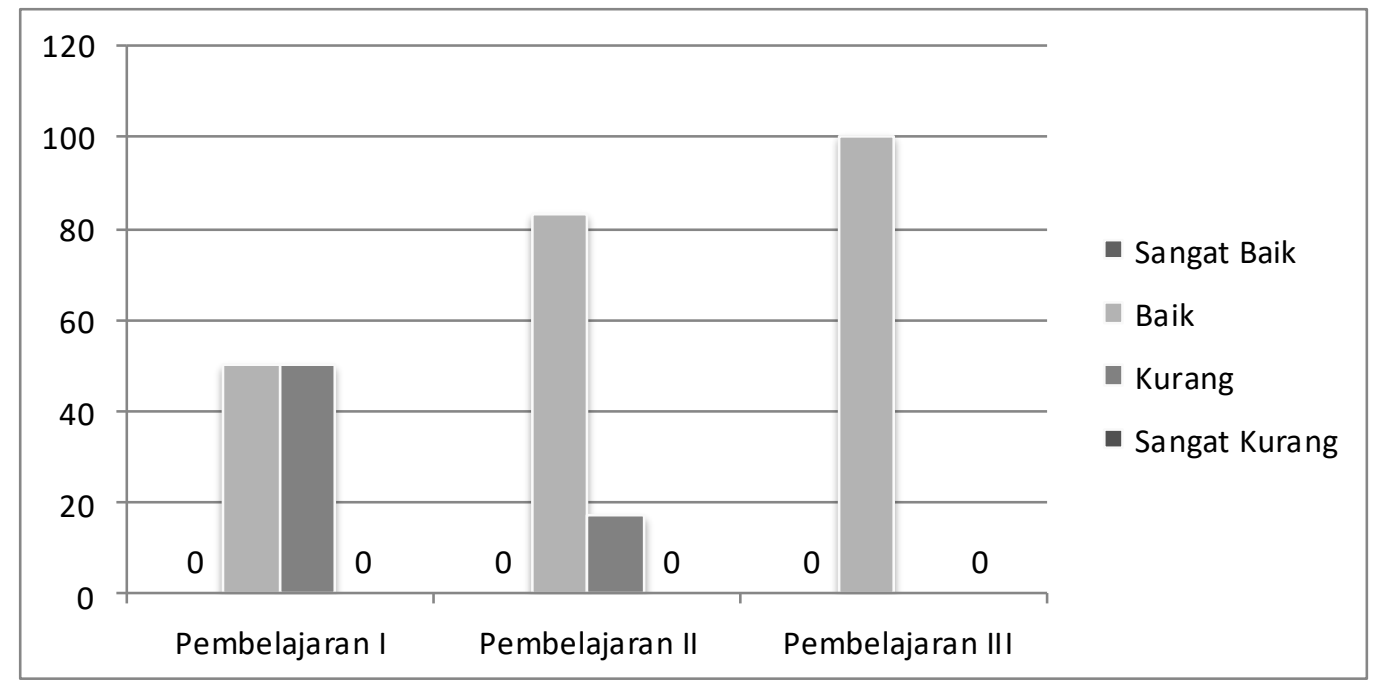

Gambar 1. Grafik Analisis Observasi Aktivitas Siswa Siklus I

Data hasil evaluasi selama proses pelaksanaan kegiatan belajar mengajar pada siklus pertama menunjukkan bahwa hasil yang diperoleh sudah baik. Siswa secara aktif dalam mengikuti proses pembelajaran dengan menjadikan Lembar Kerja Siswa sebagai pedoman belajar dan pengarahan dari guru sebagai penguatan, maka siswa lebih mudah mengerti dan memahami tugas dalam menjawab soal-soal yang ada pada LKS dan mencocokkan kartu braille. Hal ini terjadi karena sudah memahami proses belajar secara kelompok dengan metode kooperatif Make A Match. Hasil evaluasi akhir pembelajaran pada siklus pertama dalam bentuk tes menunjukkan bahwa rata-rata skor yang diperoleh siswa selaku subjek penelitian adalah 77,63 dan yang memperoleh skor 80 adalah 3 orang atau $50 \%$ , yang memperoleh skor 70 ada 2 orang atau $33,3 \%$ dan 1 orang 60 dari jumlah subjek penelitian.

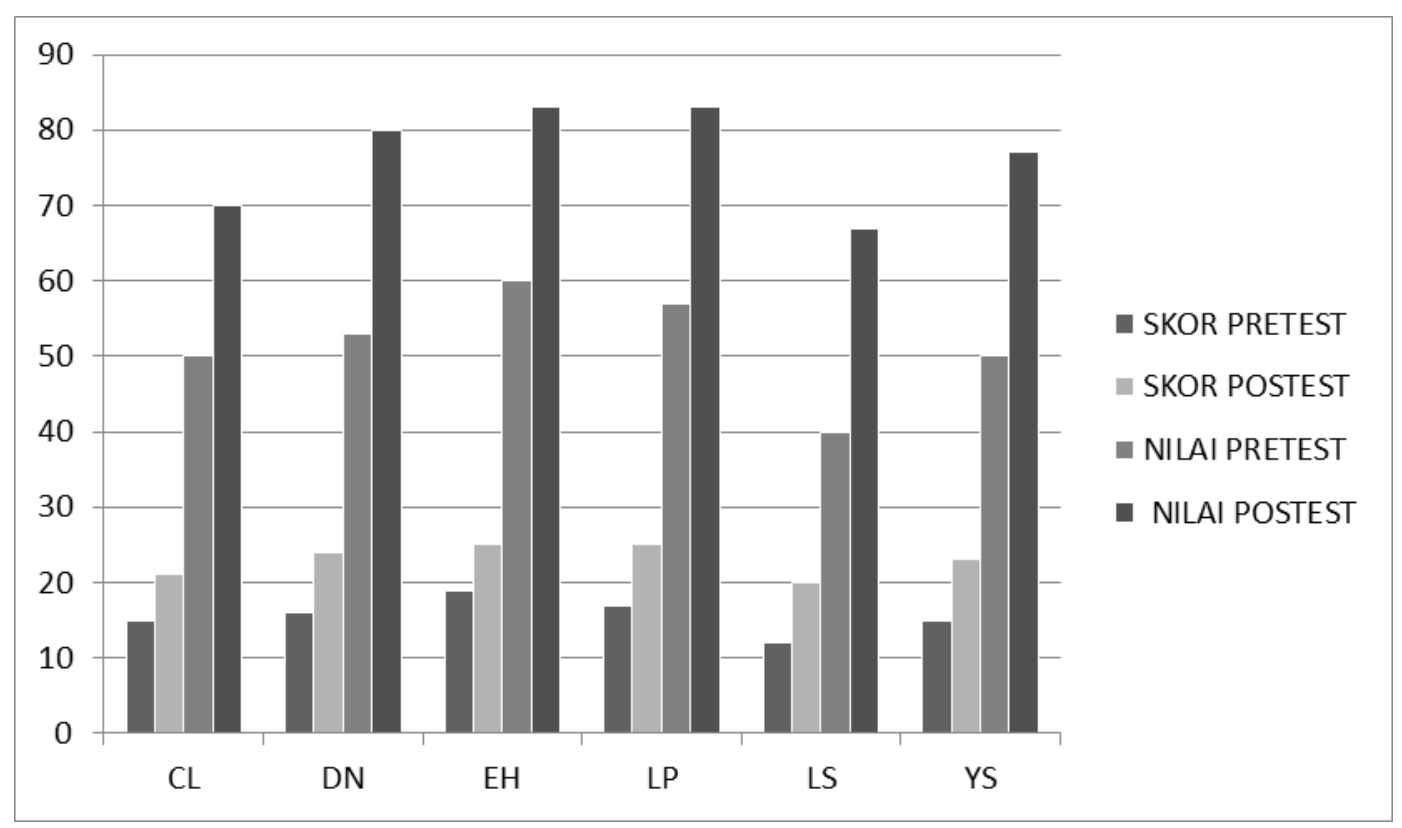

Gambar 2. Grafik Hasil Tes belajar Pretest dan Postest Siswa Siklus I 
Dari tabel dan grafik di atas dapat dilihat bahwa nilai rata-rata 51,65 meningkat menjadi 77,63. Dan yang berhasil mencapai ketuntasan belajar sebanyak lima orang $83,3 \%$, sat orang $16,7 \%$ belum mencapai ketuntasan belajar. Dari seluruh subjek penelitian yang berhasil dapat ditentukan ketuntasan belajar klasikal belum tuntas karena baru mencapai $83,3 \%$ belum mencapai $90 \%$ maka disimpulkan bahwa proses pembelajaran pada siklus 1 belum tuntas namun sangat tampak jelas adanya peningkatan hasil belajar.

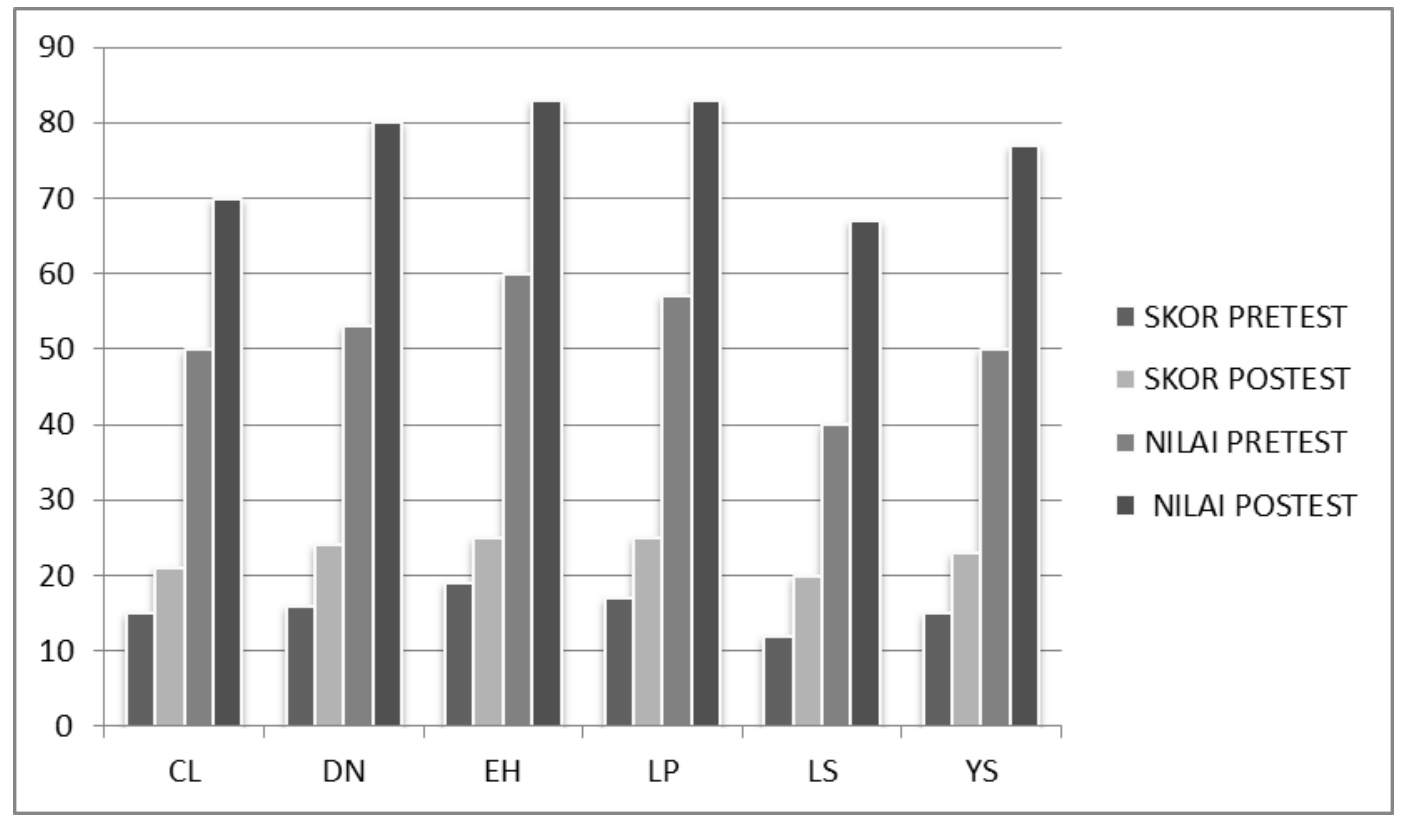

Gambar 3. Grafik Hasil Tes belajar Pretest dan Postest Siswa Siklus I

Dari tabel 3. dan grafik di atas dapat dilihat bahwa nilai rata-rata 51,65 meningkat menjadi 77,63. Dan yang berhasil mencapai ketuntasan belajar sebanyak lima orang $83,3 \%$, sat orang $16,7 \%$ belum mencapai ketuntasan belajar. Dari seluruh subjek penelitian yang berhasil dapat ditentukan ketuntasan belajar klasikal belum tuntas karena baru mencapai 83,3\% belum mencapai $90 \%$ maka disimpulkan bahwa proses pembelajaran pada siklus 1 belum tuntas namun sangat tampak jelas adanya peningkatan hasil belajar.

Hasil belajar siswa pada siklus dua ini sudah menunjukkan peningkatan yang diharapkan dibandingkan hasil belajar dari siklus sebelumnya. Siswa semakin giat belajar dengan metode pembelajaran kooperatif Make A Match dengan media kartu braille. Data hasil evaluasi selama proses pelaksanaan kegiatan belajar mengajar pada siklus dua menunjukkan bahwa hasil yang diperoleh baik. Siswa secara aktif dalam mengikuti proses pembelajaran dengan menjadikan Lembar Kerja Siswa sebagai pedoman belajar dan pengarahan dari guru sebagai penguatan, maka siswa lebih mudah mengerti dan memahami isi bacaan, menjawab soal-soal yang ada pada lembar kerja siswa (LKS) dan mencocokkan kartu braille. Hal ini terjadi karena sudah memahami proses belajar secara kelompok dengan metode kooperatif Make A Match. Hasil evaluasi akhir pembelajaran pada siklus kedua dalam bentuk tes menunjukkan bahwa rata-rata skor yang diperoleh siswa selaku subjek penelitian adalah 86,66 dan yang memperoleh skor diatas rata ada 4 orang atau $66,66 \%$, yang memperoleh skor $\geq 70$ ada enam orang dari jumlah subjek penelitian atau $100 \%$.

Sesuai data pada table di atas dapat digambarkan dengan grafik batang untuk memperlihatkan peningkatan hasil belajar siklus satu ke siklus dua seperti di bawah ini: 


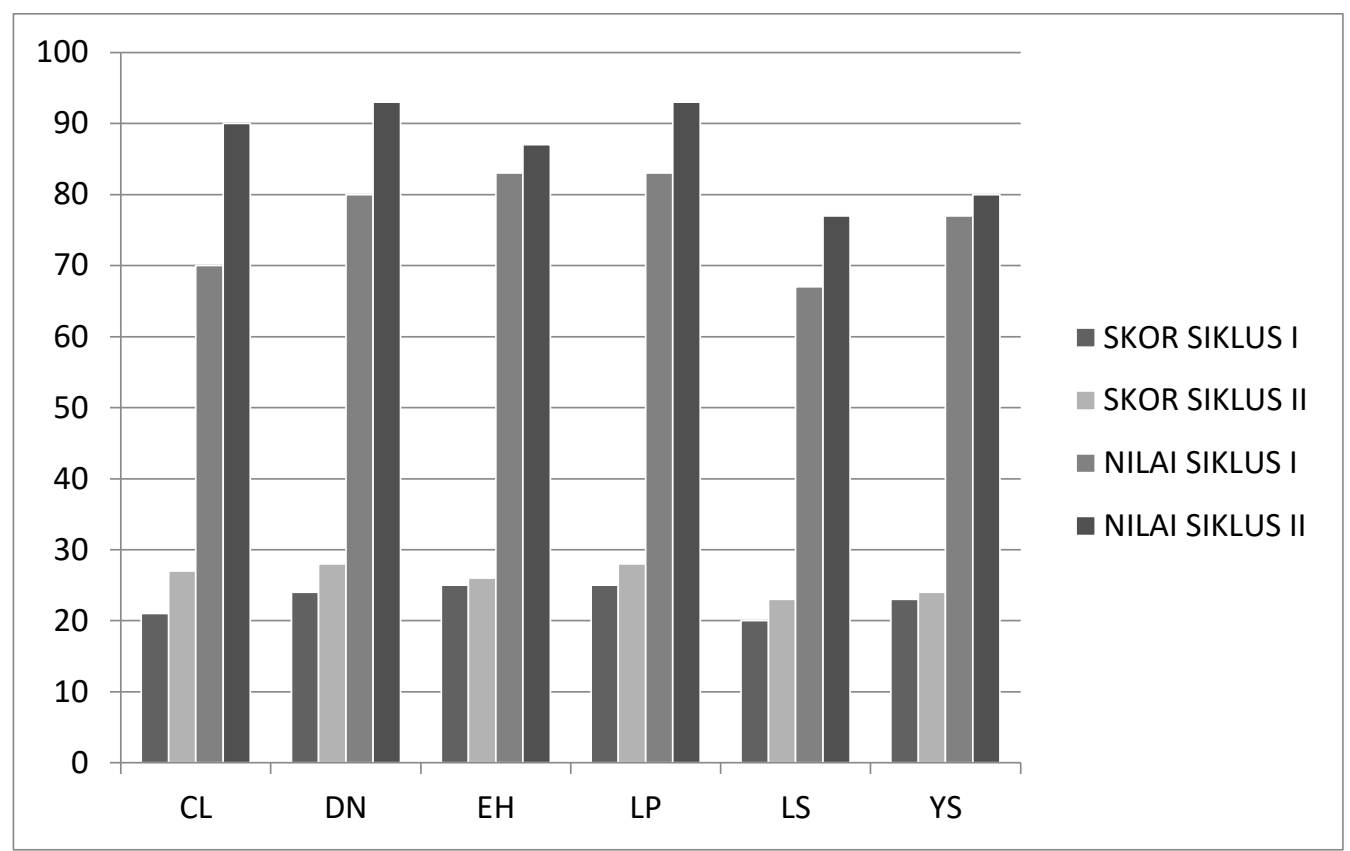

Gambar 4. Grafik Hasil Tes Belajar Siswa Siklus I dan Siklus II

Dari tabel 4 dan grafik di atas dapat dilihat bahwa nilai rata-rata 76,6 meningkat menjadi 86,00. Dan yang berhasil mencapai ketuntasan belajar pada siklus satu sebanyak lima orang 83,3\%, pada siklus dua sudah 6 orang $100 \%$ berarti ketuntasan belajar sudah tercapai. Dari seluruh subjek penelitian yang PEMBAHASAN

Dalam pembahasan penelitian ini akan dipaparkan tentang temuan penelitian yang telah dideskripsikan dan dianalisis oleh peneliti dibantu oleh kedua observer. Pada saat proses proses penelitian berlangsung terdapat dua hal yang saling berkaitan dan tidak dapat dipisahkan antara satu dengan yang lain sehingga membentuk suatu kesatuan yang utuh, yaitu antara peneliti dan subjek penelitian. Keberhasilan dari sebuah penelitian tidak dapat dipisahkan dari kedua faktor tersebut di atas terutama faktor guru atau peneliti itu sendiri, karena dalam penelitian ini guru memiliki peran yang sangat penting sekali, gurulah yang akan menyajikan dan mengarahkan subjek penelitian. Dalam penelitian ini guru mata pelajaran memiliki peran ganda, yang pertama berperan sebagai pengajar dan yang kedua berperan sebagai peneliti. Makanya guru bertanggungjawab penuh terhadap proses penelitian mulai dari tahap persiapan, pelaksanaan penelitian sampai pada akhir melakukan pengevaluasian hasil penelitian. berhasil dapat ditentukan ketuntasan belajar klasikal apabila mencapai $90 \%$ maka disimpulkan bahwa proses pembelajaran pada siklus II secara individu maupun klasikal sudah tuntas.

Guru mata pelajaran yang juga bertindak sebagai peneliti tidak menemukan kendalakendala yang sangat berarti dalam melaksanakan, membimbing, dan mengevaluasi proses pembelajaran dengan penerapan metode pembelajaran kooperatif Make A Match. Hal ini dikuatkan oleh hasil observasi kegiatan guru yang menunjukkan bahwa guru mampu menjalankan atau melaksanakan point demi point yang terdapat dalam format observasi kegiatan guru (lampiran). Atau dengan kata lain guru telah memenuhi kriteria indikator kebehasilan tindakan yang terdapat dalam penelitian ini.

Siswa tunanetra kelas VI SLB-A Yapentra yang dijadikan subjek penelitian juga mampu melaksanakan perannya dengan baik dalam membahas materi sesuai dengan format yang telah ditentukan sebelumnya sehingga penelitian ini dapat mencapai suatu keberhasilan yang memuaskan. Peneliti juga sangat memperhatikan apakah indikator kegiatan siswa sudah terlaksana dengan baik sesuai dengan format yang telah ditetapkan 
sehingga keaktifan siswa selalu terpantau dan terjaga.

Meningkatnya kemampuan siswa tunanetra kelas VI dalam meguasai materi tentang "Membaca Intensif" pada mata pelajaran Bahasa Indonesia dapat dilihat dari beberapa faktor seperti respon siswa terhadap pembelajaran, dan hasil tes yang dilaksanakan pada akhir tindakan. Khususnya pada tes akhir tindakan siklus II skor rata-rata kelas telah mencapai $86,66 \%$, siswa yang mencapai $\geq 70 \%$ adalah $100 \%$. Dari data tersebut di atas dapat disimpulkan bahwa terjadi peningkatan terhadap kemampuan siswa kelas VI SLB-A Yapentra dalam menguasai materi membaca intensif. Hasil penelitian yang dikemukakan dalam penelitian ini mengalami peningkatan yang sangat baik. Hal ini relevan dengan hasil penelitian yang dikemukakan oleh peneliti lain dengan menggunakan metode kooperatif Make A Match pada pokok bahasan yang berbeda.

Tanggapan siswa tentang metode mengajar yang digunakan dalam proses pembelajaran juga dapat dilihat dari berbagai unsur mulai dari perasaan masing-masing individu seperti ekspresi diri, senyuman, mau bertanya jika ada sesuatu yang kurang dimengerti, dan siswa juga tidak segan-segan dalam memberikan pujian seperti bertepuk tangan jika jawaban rekannya benar, siswa terlihat secara aktif dalam bekerja sama dalam kelompok teristimewa dalam mencocokkan kartu berpasangan.

Melalui proses pembelajaran dengan menggunakan metode kooperatif Make A Match siswa memiliki berbagai cara atau pariasi dalam mengekspresikan diri dalam hal mengemukakan pendapat maupun dalam hal menanggapi pendapat dalam kelompok guna menguatkan pemahaman materi yang dipelajari. Kooperatif Make A Match merupakan metode pembelajaran yang sangat fleksibel dan mengarahkan siswa sebagai pebelajar yang aktif dalam suasana yang menyenangkan baik individual maupun kelompok. Sehingga pada akhirnya dapat menambah wawasan dan pengetahuan, serta siswa juga dapat mengetahui dan memahami isi, materi atau masalah yang ada dalam teks saat belajar membaca intensif.

Dari pemaparan hasil temuan penelitian di atas dapat disimpulkan bahwa siswa yang merupakan subjek dalam penelitian ini, telah memenuhi kriteria ketuntasan belajar. Dalam penelitian ini siswa mampu menunjukkan sikap positif pada saat pembelajaran berlangsung dan begitu juga setelah kegiatan pembelajaran berlangsung seperti: (a) siswa mampu berdiskusi, bekerja sama dalam kelompok dalam mengerjakan tugas kelompok; (b) siswa dapat menemukan pesan tersurat maupun tersirat dari sebuah wacana yang dibaca ; (c) siswa dapat menjelaskan unsur-unsur yang terkandung dalam teks drama yang dibaca; (c) Hasil belajar siswa telah memenuhi kriteria ketuntasan belajar yang merujuk pada skor ketuntasan belajar SLB-A yaitu: $\geq 70$ dan yang memperoleh skor $\geq 70$ harus $5 \%$ peserta (siswa). Siswa yang dianggap tuntas secara individu dalam proses pembelajaran apabila sudah mencapai skor $\geq 70$ dan tuntas secara klasikal apabila $\geq 90 \%$ dari jumlah keseluruhan siswa dalam satu kelas telah mencapai skor tersebut. Jika skor tersebut tercapai barulah ketuntasan belajar dianggap berhasil.

\section{PENUTUP}

Simpulan penelitian ini didasarkan pada hasil analisis data proses pembelajaran dan hasil tes akhir tindakan, maka dapat diambil kesimpulan sebagaimana berikut: Pertama, dengan menerapkan metode pembelajaran kooperatif Make A Match dengan media kartu braille, aktivitas siswa dalam setiap siklus terus meningkat terutama ketika siswa dibagi kedalam kelompok dalam mencocokan pasangan kartu braille. Kedua, dengan menerapkan metode pembelajaran kooperatif Make A Matc dengan media kartu braille dapat meningkatkan hasil belajar Bahasa Indonesia khususnya dalam pembelajaran "Membaca Intensif"

\section{DAFTAR PUSTAKA}

Alma, B. (2008). Guru Profesional: Menguasai Metode dan Terampil Mengajar.

Bandung: Alfabeta

Anderson, O.W. dan Krath Wohl, D.R. (2001). A Taxonomy for Learning, Teaching and Assessin. New York: Addison Wesley Logman, Inc

Asrori, M, H. (2007). Penelitian Tindakan Kelas. Bandung: Wacana Prima.

Barraga dalam Yusuf M (2001). Pendidikan Tunanetra Dewasa dan Pembinaan Karir. Jakarta: Depdiknas

Best, A (1997). "Managemen Issues in Multiple Disabilities". Dalam Mason H \& Mc Call. S. (1997). Visual Impairment Acces 
to Education for Children and Young People. London: David Fulton Publishers.

Bloom, B.S (1964). Taxonomy of Education Objektive: Cognitive Domain. New York: David McKay

Dimyanti dan Mudjiono (1999). Belajar dan Pembelajaran. Jakarta: Rineka Cipta

Depdiknas, (2003) Undang-undang Nomor 20 Tahun 2003 tentang Sistem Pendidikan Nasional. Dirjen PMPTK, Jakarta.

Driscoll, M.P. (1993). Psychology of Learning for Instruction. Boston: Florida State University

Dirjen Pembina Sekolah Luar Biasa (2006). Standar Kompetensi dan Kompetensi Dasar. Jakarta: Depdiknas

Gagne, R.M, \& Leslie J. B. (1977) Principles of Instructional Design. New york; Holt Rinerhart and Winston.

Gagne, R.M \& Driscoll, M.P. (1989). Essential of Learning for Instruction. New Jersey: Prentice Hall

Gagne RM (1985). The Conditions of Learning and Theory of Instruction. New York: Reinehart and Winston

Gagne RM dan Briggs LJ (1979). Principle of Instructional Design. New York: Holt, Reinehart and Winston

Gagne RM (1977). The Condition of Learning. USA: Holt, Reinehart and Winston

Hamalik, O. (1994). Kurikulum dan Pembelajaran. Bumi Aksara: Jakarta.

Hamalik O. (2010) Proses Belajar Mengajar. Jakarta: Pt. Bumi Aksara.

Hamin, H.A. (1996) Pendidikan Ilmu Sosial, Jakarta: Proyek Pendidikan Tenaga Akademik Dirjen Dikti Depdikbud.

Harjanto (2008) Perencanaan Pengajaran. Jakarta. Rineka Cipta.

Hosni I (1996). Orientasi \& Mobilitas. Jakarta: Direktorat Pendidikan Tinggi

Hopkins D. (1993). A Teacher's Guide to Classroom Research. Philadelphia: Open University Press

Isjoni (2009). Pembelajaran Kooperatif. Yogyakarta: Pustaka Pelajaran

Kagan,S. (1992). Cooperative learning resources for teachers. San Juan Capistrano, CA: Resources for Teachers.

Kemmis S. Mc. Taggart. R. (1992). The Action Research Plane, Victoria: Deaken University

Kingsley, M (1997). "The Effect of Visual loss: Dalam Mason H \& Mc Call, S (1997).
Visual Impairment Acces to Education for Children and Young People. London: David Fulton Publishers

Lowenfels, B. (1979). Anak Tunanetra di Sekolah. Jakarta: BP3K

Lie, A (1999). Metode Pembelajaran Gotong Royong. Surabaya: Citra Media.

Lie, A (2000). Cooperative Learning: Mempraktekkan Cooperative Learning di Ruang-ruang Kelas. Jakarta: Grasindo

Lie, A (2010) Cooperative Learning: Mempraktekkan Cooperative Learning di Ruang-Ruang Kelas. Jakarta: PT Gramedia.

Reigelut, C. (1983) Instructional Design: Theories and Overview of Their Current Status. New Jersey: Lawrence Erlbaum Associates, Publishers Hillsdale

Reynell J, and Moodley (1978). Helping Language Development: A Developmental Programme for Children Whit Learning Handicaps. London: Edwar Arnold.

Romizwoski, AJ. (1981). Designig Instruction Systems, (Decision Making in Caurse Planning and Curriculum Design). London: Kogam Page Schmeck

Sagala, S. (2011). Konsep dan Makna Pembelajaran. Bandung: Alfabeta

Sanjaya, W. (2005). Pembelajaran dalam Implementasi Kurikulum Berbasis Kompetensi Jakarta: Kencana Prenada Media Group

Sanjaya, W. (2006). Strategi Pembelajaran Beriorentasi Standart Proses Pendidikan. Jakarta: Kencana Prenada Media Gruop

Sanjaya, W. (2008). Perencanaan dan Desain Sistem Pembelajaran. Jakarta: Kencana Prenada Media Group.

Sardiman A.M. (2008) Interaksi dan Motivasi Belajar Mengajar, Jakarta: Bumi Aksara.

Sardiman, A.M. (2011) Interaksi dan Motivasi Belajar Mengajar. Jakarta: Rajawali Press.

Slameto (1991) Belajar dan Faktor-Faktor yang mempengaruhinya. Jakarta: Rineka Cipta

Slavin, R.E. (1993) Cooperative Learning and Achievement An Empiri Cally-Based theory. Paper presented at the annual meeting of the American Educational Research Association, Atlanta

Slavin, R.E. (2005) Cooperative Learning Teori, Risert dan Praktik. London: Allymand Bacon 
Stahl. R.I. (1994) Cooperative Learning in Social Studies America: Addision Wesley Publishing Company, Inc

Sunarto dan Agung H. (1945). Perkembangan Peserta Didik. Jakarta: Rineka Cipta.

Suprijono A. (2010). Cooperatif Learning TEORI \& APLIKASI PAIKEM. Yogyakarta: Pustaka Pelajar

Tarigan, H.G. (2005) Membaca. Bandung: Angkasa
Trianto. (2008). Mendesain Pembelajaran Kontekstual Di Kelas. Jakarta. Cerdas Pustaka Publisher.

Warsita, Bambang (2008). Teknologi Pembelajaran. Landasan dan Aplikasi. Jakarta: Rineka Cipta.

Wibawa, B., Mukti, F. (2001). Media Pengajaran :Bandung: Maula 